\title{
Implementing Response to Intervention (RtI) and Early Reading: A Review of Literature
}

\author{
San Juanita Rios-Sobrevilla \\ Texas A\&M International University \\ 5201 University Blvd., Killam 432, Laredo, TX 78045-1900 \\ Tonya Huber (Corresponding author) \\ Texas A\&M International University \\ 5201 University Blvd., Killam 432, Laredo, TX 78045-1900 \\ E-mail: Tonya.Huber@TAMIU.edu
}

Received: June 14, 2019 Accepted: Oct. 21, $2019 \quad$ Published: November 1, 2019

doi:10.5296/jse.v9i4.15551 URL: https://doi.org/10.5296/jse.v9i4.15551

\begin{abstract}
Background: Response to Intervention (RtI) in early reading is known as the detailed process that is implemented to enhance the areas of reading in young children.

Aims: The reviewers compare various approaches to Response to Intervention (RtI) and identify which frameworks are reported as most effective for young early readers.

Method: The topic of Response to Intervention (RtI) in early reading was studied through a comprehensive review of the literature.

Findings: Research results all show the overall improvement of student performance in reading as well as overall teacher growth in knowledge, delivery of instruction, confidence, and self-efficacy.

Conclusion: Response to Intervention (RtI) in early reading has proven to be a successful and effective approach deserving the necessary attention by school staff and administration to be properly aligned and appropriately implemented.
\end{abstract}

Keywords: response to intervention, early reading, teacher judgment 


\section{MlMacrothink}

\section{Introduction}

Response to Intervention (RtI) is a detailed process that is implemented to enhance the areas of reading within the following pathways: (a) phonological pathway including rhyming, blending, and segmenting; (b) orthographic pathway including segmenting and blending onset and rime in multisyllabic words; and (c) oral language pathway which include a set of comprehension skills that are applied to reading (Munro, 2017, p. 137). RtI in early reading can be administered through a variety of approaches. Some examples of approaches for RtI are the use of a database framework with the implementation of instruction, use of a supplemental online reading program, or even a data-driven coaching model that supports the educator in delivery of RtI. Studies present that teachers can certainly identify the student that requires intervention, but not always make the best judgment in how to intervene. Identifying a student who requires intervention may not always generate positive results. In one particular study, researchers noted that "none of the teachers selected the same intervention for their student that was identified most promising in a brief experimental analysis" (Wagner, Coolong-Chaffin, \& Deris, 2017, p. 368). The most novice to the most experienced teachers could be further supported in making the best decisions about interventions for their students. So it leaves to question then, what is the missing link? As educators, where are we going wrong with the intervention process and what can we do to intervene the most effectively?

The purpose of this analysis of peer-reviewed literature is to compare RtI practices and the factors that are crucial in helping to implement the RtI process most effectively. This review is aimed particularly at aiding students who are in the early reading stage of development and require intervention. One finding, in particular, will show how the selected RtI approach not only impacted the performance growth of the student, but also the overall growth of the educator.

Being that some of the terms in this analysis are used in everyday teaching vernacular, a table of terms is provided "making it easy for the reader to scan the definitions" (Galvan \& Galvan, 2017 , p. 88) to gain the fullest meaning of this analysis. Some of the terms used in the search were related to reading in general but not specific to RtI. The terms in the literature reviewed that specifically linked reading intervention and early reading are provided in Table 1. 
Table 1. Terms and Definitions Related to Response to Intervention (RtI)

\begin{tabular}{|c|c|}
\hline Term & Definition and Source(s) \\
\hline MTSS & $\begin{array}{l}\text { The acronym for multi-tiered systems of support (Coyne, Leonard, \& } \\
\text { Burns, 2016, p. 67). }\end{array}$ \\
\hline $\begin{array}{l}\text { reading } \\
\text { difficulties }\end{array}$ & $\begin{array}{l}\text { "Early reading difficulties can be determined or identified 'causes, such } \\
\text { as dyslexia' or limited reading comprehension that hinder the student in } \\
\text { reaching or succeeding in current grade level performance" (Munro, } \\
2017, \text { p. 134). }\end{array}$ \\
\hline $\begin{array}{l}\text { reading } \\
\text { instruction }\end{array}$ & $\begin{array}{l}\text { "Instruction targeting the five components of reading such as phonemic } \\
\text { awareness, phonics, vocabulary, fluency, and reading comprehension" } \\
\text { (Tyler, Hughes, Beverley, \& Hastings, 2015, pp. 283-284). }\end{array}$ \\
\hline $\begin{array}{l}\text { response to } \\
\text { intervention (RtI) }\end{array}$ & $\begin{array}{l}\text { "RtI is a detailed process that is implemented to enhance the areas of } \\
\text { reading within the following pathways: (a) phonological pathway } \\
\text { including rhyming, blending, and segmenting; (b) orthographic pathway } \\
\text { including segmenting and blending onset and rime in multisyllabic } \\
\text { words; and (c) oral language pathway which include a set of } \\
\text { comprehension skills that are applied to reading (Munro, 2017, p. 137). }\end{array}$ \\
\hline $\begin{array}{l}\text { supplementary } \\
\text { instruction }\end{array}$ & $\begin{array}{l}\text { "Reading instruction indicating an explicit, systematic, and intensive } \\
\text { framework that is administered aside from typical in-class core } \\
\text { instruction" (Tyler, Hughes, Beverley, \& Hastings, 2015, pp. 283-284). }\end{array}$ \\
\hline teacher judgment & $\begin{array}{l}\text { "The ability to determine students' specific reading levels of } \\
\text { performance, identify students who are the most at risk of reading failure, } \\
\text { and evaluating reading progress over time and deciding how to intervene" } \\
\text { (Wagner, Coolong-Chaffin, \& Deris, 2017, p. 350). }\end{array}$ \\
\hline
\end{tabular}

\section{Methodology}

Five peer-reviewed articles were identified through thorough searches using the WorldCat database. Searches were narrowed down by the choice of filters during the search. Filters used in the database search were last five years, WorldCat, peer-reviewed, full text, and Texas A\&M International University Killam Library. Applying these filters allowed for a practical size of returns in comparison to a large number totaling over the thousands. An additional step taken in the search was the addition of Boolean operators and quotation marks, to narrow down a topic of interest (Galvan \& Galvan, 2017, p. 22). Working with a feasible list of returns, less than 150, the lead author then filtered through the articles "starting with the most current journal articles" (p. 33). In the column of relevant sources, the numbers are low because the content of most articles did not align with participants that included young 


\section{NI Macrothink}

Journal of Studies in Education

ISSN 2162-6952

2019, Vol. 9, No. 4

early readers within primary grades. Though there was an abundance of returned articles from the search terms chosen, very few targeted early childhood. A majority of the articles related to middle school or high school students, whereas the specifical target was early reading ages, Kinder to $2^{\text {nd }}$-grade. A complete audit trail of the search process is documented in Table 2. In Figure 1, a screenshot displays an initial result from the searches and selected filters. (The research was begun in summer 2019 and all search terms were re-evaluated in October one the manuscript was accepted for publication to insure the most current results).

Table 2. Audit Trail of Database Searches

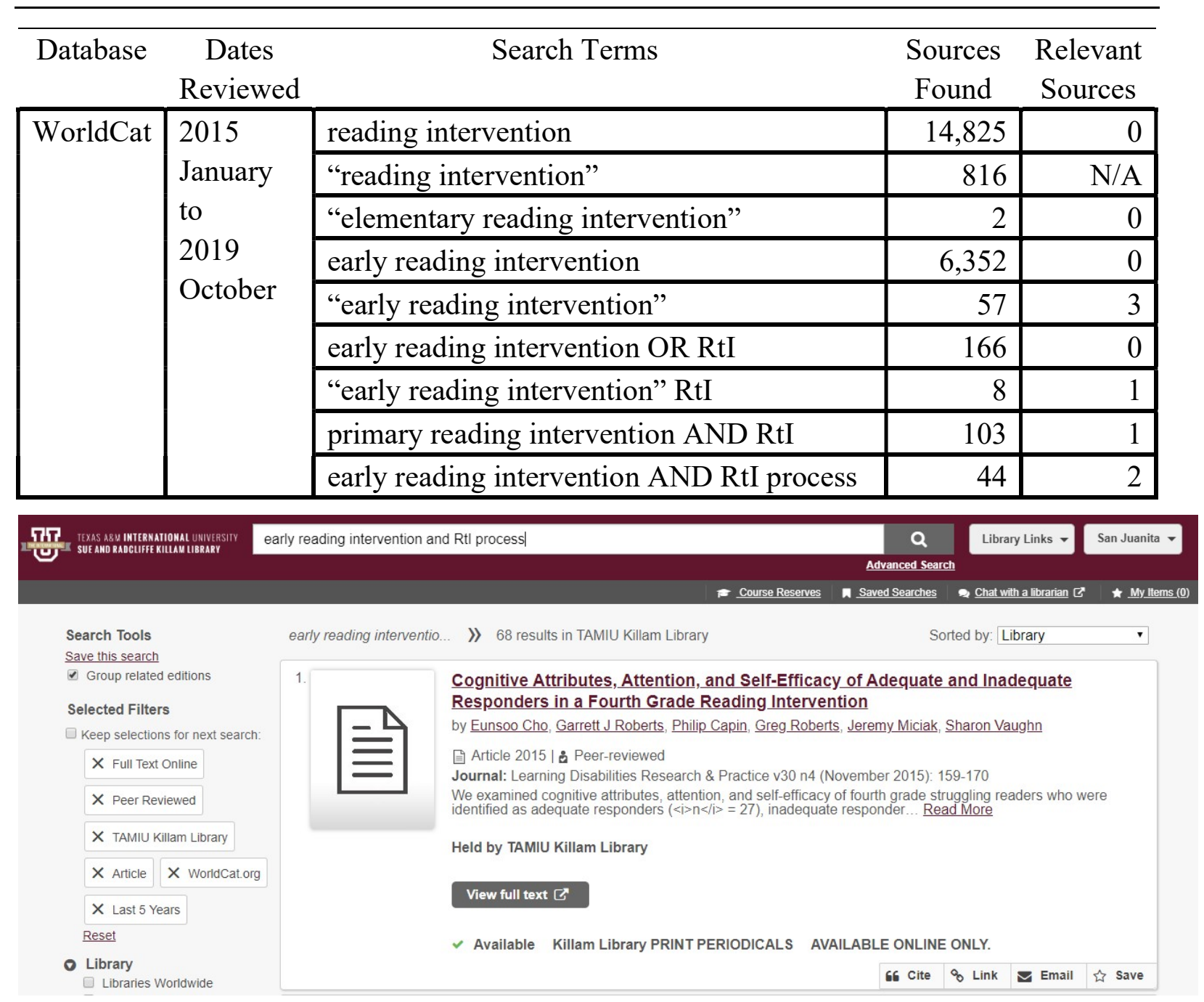

Figure 1. Screenshot of Search Terms

\section{Analysis}

In Table 3, information regarding the methodologies and findings of all 5 articles that were reviewed can be considered. Column one lists the author, publication year, and the participants for each article. The second column lists the methodologies used during the study. Columns three and four list the related topic definition of RtI and the specified program of a framework of all five articles. In all of the articles, Response to Intervention 
and early reading were the primary focus. The studies differed from one another concerning the type of intervention that was utilized. The similarity throughout the 5 articles was participants' use of early childhood students performing in the early reading stages of development. The final column includes the summary of findings for each article. The summary of the results is written in a narrative description to represent the fullest meaning (Galvan \& Galvan, 2017, p. 91).

Table 3. Methodologies and Findings Related to RtI and Early Reading

\begin{tabular}{|c|c|c|c|c|}
\hline $\begin{array}{c}\text { Authors, } \\
\text { Publication Year, } \\
\text { and Participants }\end{array}$ & $\begin{array}{c}\text { Detailed } \\
\text { Methodology }\end{array}$ & $\begin{array}{l}\text { Response to } \\
\text { Intervention } \\
\text { (RtI) and } \\
\text { Early } \\
\text { Reading }\end{array}$ & Program & Summary of Findings \\
\hline $\begin{array}{l}\text { Coyne, Leonard, } \\
\& \text { Burns (2016) } \\
\text { Participants: } \\
427 \text { students of } \\
\text { primary age: } \\
67 \% \text { Hispanic, } \\
16 \% \\
\text { African-American, } \\
12 \% \text { White } \\
83 \% \text { receiving } \\
\text { reduced lunch } \\
33 \% \text { receiving } \\
\text { ELL services. }\end{array}$ & $\begin{array}{l}\text { The participating } \\
\text { school received: } \\
\text { Professional } \\
\text { development, } \\
\text { Interventionists } \\
\text { support, and } \\
\text { Assistance from } \\
\text { external coaches } \\
\text { to implement } \\
\text { multi-tiered } \\
\text { systems of } \\
\text { support (MTSS) } \\
\text { practices and } \\
\text { systems. }\end{array}$ & $\begin{array}{l}\text { "the practices } \\
\text { associated } \\
\text { with } \\
\text { multi-tiered } \\
\text { systems of } \\
\text { support in } \\
\text { beginning } \\
\text { reading" } \\
\text { (p. } 67) .\end{array}$ & $\begin{array}{l}\text { K-3 Reading } \\
\text { Initiative, in } \\
\text { which goals } \\
\text { were to } \\
\text { "implement } \\
\text { and evaluate a } \\
\text { fully specified } \\
\text { school-wide } \\
\text { multi-tiered } \\
\text { K-3 reading } \\
\text { school } \\
\text { improvement } \\
\text { model" } \\
\text { (p. 69). }\end{array}$ & $\begin{array}{l}\text { "Though the multi-tiered } \\
\text { systems of support (MTSS) } \\
\text { model, K-3 Reading } \\
\text { Initiative, did offer } \\
\text { promising results with } \\
\text { participating schools, it was } \\
\text { that of the delving into the } \\
\text { details that lead to } \\
\text { complications and } \\
\text { challenges. For any reading } \\
\text { framework to "work" } \\
\text { participating schools must } \\
\text { meet the challenges with a } \\
\text { strong foundation and } \\
\text { support of strong teacher } \\
\text { leadership, high-quality } \\
\text { classroom instruction, data } \\
\text { analysis and interpretation, } \\
\text { and time prioritization" (p. } \\
\text { 83). In conclusion, it is } \\
\text { important to keep in mind } \\
\text { exactly what it is that the } \\
\text { findings in this study imply. } \\
\text { Not only was the } \\
\text { multi-tiered system of } \\
\text { support used, but rather it } \\
\text { was the commitment and } \\
\text { diligent work of staff and } \\
\text { personnel that made the } \\
\text { obvious impact. "The }\end{array}$ \\
\hline
\end{tabular}




\begin{tabular}{|c|c|c|c|c|}
\hline & & & & $\begin{array}{l}\text { supports that schools need } \\
\text { to build systems and } \\
\text { infrastructure to implement } \\
\text { and sustain such practices } \\
\text { are often overseen" (p. 68). }\end{array}$ \\
\hline $\begin{array}{l}\text { Glover (2017) } \\
\text { Participants: } \\
\text { Kinder-3 }{ }^{\text {rd }} \text { grade } \\
\text { elementary } \\
\text { teachers, coaches, } \\
\text { consultants, } \\
\text { interventionists, } \\
\text { and school } \\
\text { stakeholders or } \\
\text { administrators. }\end{array}$ & $\begin{array}{l}\text { Teacher practice, } \\
\text { Ongoing } \\
\text { feedback, } \\
\text { Formulized } \\
\text { data-driven } \\
\text { implementation } \\
\text { framework. }\end{array}$ & $\begin{array}{l}\text { "a } \\
\text { multi-tiered } \\
\text { prevention } \\
\text { model } \\
\text { wherein } \\
\text { students' } \\
\text { performance } \\
\text { relative to } \\
\text { predefined } \\
\text { benchmarks } \\
\text { is identified } \\
\text { through } \\
\text { systematic } \\
\text { screening”, } \\
\text { (p. 13). }\end{array}$ & $\begin{array}{l}\text { Data-Driven } \\
\text { Coaching } \\
\text { Model, } \\
\text { comprised of } 3 \\
\text { main } \\
\text { components: } \\
\text { an emphasis on } \\
\text { the learning } \\
\text { environment, } \\
\text { enrollment of } \\
\text { teachers via } \\
\text { modeling, } \\
\text { designated } \\
\text { opportunities } \\
\text { for feedback, } \\
\text { and the use of a } \\
\text { formalized } \\
\text { data-driven } \\
\text { implementation } \\
\text { framework. }\end{array}$ & $\begin{array}{l}\text { "With this approach, which } \\
\text { is guided by a behavior } \\
\text { consultation framework, } \\
\text { change is presumed to occur } \\
\text { as a result of the influence } \\
\text { of coaching actions and } \\
\text { teachers' perceptions and } \\
\text { self-efficacy" (p. 19). } \\
\text { In this case in study, the } \\
\text { findings explain how a } \\
\text { data-driven coaching model } \\
\text { helps zoom in on the } \\
\text { behavior and environment } \\
\text { of the teacher rather than } \\
\text { that of the student, and how } \\
\text { to build on the teacher's } \\
\text { abilities to perform. "The } \\
\text { data-driven instructional } \\
\text { coaching model extends the } \\
\text { focus beyond behavioral } \\
\text { change to incorporate } \\
\text { changes in instructional } \\
\text { practices and skills" (p. 14). } \\
\text { The foundation of the } \\
\text { model, being that of } \\
\text { coaching support, will serve } \\
\text { as the catalyst to drive } \\
\text { future outcomes for both } \\
\text { teacher and student. }\end{array}$ \\
\hline $\begin{array}{l}\text { Munro (2017) } \\
\text { Participants: } \\
902 \\
\text { underachieving } \\
\text { students, } \\
1^{\text {st }} 4^{\text {th }} \text { grade, } \\
53 \text { Catholic } \\
\text { schools, }\end{array}$ & $\begin{array}{l}\text { Neale } \\
\text { Assessment } \\
\text { (Analysis of } \\
\text { Reading Ability) } \\
\text { pre- and } \\
\text { post-intervention } \\
\text { 3-way } \\
\text { intervention }\end{array}$ & $\begin{array}{l}\text { "effective } \\
\text { approaches } \\
\text { to reading in } \\
\text { need to target } \\
\text { the specific } \\
\text { causes for } \\
\text { individual } \\
\text { readers" } \\
\text { (p. 133). }\end{array}$ & $\begin{array}{l}\text { The Early } \\
\text { Reading } \\
\text { Intervention } \\
\text { Knowledge } \\
\text { program, } \\
\text { (ERIK) } \\
\text { comprised of } \\
\text { three } \\
\text { intervention }\end{array}$ & $\begin{array}{l}\text { "The three pathways were } \\
\text { all associated with improved } \\
\text { reading accuracy and } \\
\text { comprehension, with effect } \\
\text { sizes of } 1.0 \text { in each case } \\
\text { indicating a substantial to } \\
\text { large improvement" (p. } \\
\text { 147). The pathways were a } \\
\text { vital part of the intervention }\end{array}$ \\
\hline
\end{tabular}




\begin{tabular}{|c|c|c|c|c|}
\hline $\begin{array}{l}\text { metropolitan area, } \\
\text { age and gender } \\
\text { were not recorded. }\end{array}$ & pathways. & & $\begin{array}{l}\text { pathways } \\
\text { including } \\
\text { phonological } \\
\text { phonemic, } \\
\text { phonic } \\
\text { orthographic, } \\
\text { and oral } \\
\text { language. }\end{array}$ & $\begin{array}{l}\text { process but the role of the } \\
\text { student reading profile also } \\
\text { played an intricate part. It } \\
\text { was the "importance that } \\
\text { was taken into account each } \\
\text { reading profile" that made } \\
\text { an impact on the } \\
\text { improvement of student } \\
\text { outcomes (p. 147). }\end{array}$ \\
\hline $\begin{array}{l}\text { Tyler, Hughes, } \\
\text { Beverley, \& } \\
\text { Hastings (2015) } \\
\text { Participants: } \\
51 \text { children, } \\
\text { ages 6-7 years in } 2 \\
\text { mainstreamed } \\
\text { schools, } \\
\text { participants } \\
\text { randomly } \\
\text { allocated. }\end{array}$ & $\begin{array}{l}\text { Pretest reading } \\
\text { assessments, } \\
\text { Eighty } \\
\text { 20-minute } \\
\text { lessons, } \\
80 \text { stories, } \\
\text { period of } 8 \\
\text { months. }\end{array}$ & $\begin{array}{l}\text { "effective } \\
\text { approaches } \\
\text { for teaching } \\
\text { reading to } \\
\text { typically } \\
\text { developing } \\
\text { children" } \\
\text { (p. } 282) \text {. }\end{array}$ & $\begin{array}{l}\text { HeadSprout } \\
\text { Early Reading } \\
\text { (HER) } \\
\text { Program } \\
\text { including } \\
\text { lessons in } \\
\text { diagnostic } \\
\text { reading } \\
\text { analysis, } \\
\text { oral reading } \\
\text { fluency, } \\
\text { dynamic } \\
\text { indicator of } \\
\text { basic early } \\
\text { literacy } \\
\text { internet-based. }\end{array}$ & $\begin{array}{l}\text { "Although this was a small } \\
\text { study, the results indicate } \\
\text { that using HER as a } \\
\text { supplementary reading } \\
\text { instruction for young } \\
\text { beginning readers can have } \\
\text { a significant effect on } \\
\text { reading skills" (p. 292). } \\
\text { The HER program was } \\
\text { conducted outside of core } \\
\text { classroom instruction. The } \\
\text { added intervention } \\
\text { supplement of an online } \\
\text { reading program added } \\
\text { additional hours of reading } \\
\text { practice for the student. } \\
\text { "The findings contribute to } \\
\text { the evidence base indicating } \\
\text { the potential benefits of } \\
\text { such programs to provide } \\
\text { additional support for } \\
\text { beginning readers" (p. 292). }\end{array}$ \\
\hline $\begin{array}{l}\text { Wagner, } \\
\text { Coolong-Chaffin, } \\
\text { \& Deris (2017) } \\
\text { Participants: } \\
3 \text { elementary } \\
\text { teachers, } \\
3 \text { elementary } \\
\text { students, } \\
\text { ( } 2 \text { Kindergarten } \\
\text { and } 1 \text { second- } \\
\text { grade student). }\end{array}$ & $\begin{array}{l}\text { Prior and } \\
\text { post-study } \\
\text { interviews; } \\
\text { consistent and } \\
\text { on-going } \\
\text { feedback. }\end{array}$ & $\begin{array}{l}\text { "critical } \\
\text { instructional } \\
\text { and service } \\
\text { allocation } \\
\text { decisions that } \\
\text { impact the } \\
\text { students" } \\
\text { reading } \\
\text { performance" } \\
\text { (p. 349). }\end{array}$ & $\begin{array}{l}\text { Brief } \\
\text { Experimental } \\
\text { Analysis } \\
\text { (BEA), to test } \\
\text { the effects of } 4 \\
\text { different types } \\
\text { of } \\
\text { interventions. } \\
\text { Comparison of } \\
\text { teacher } \\
\text { suggested } \\
\text { intervention }\end{array}$ & $\begin{array}{l}\text { "The findings presented that } \\
\text { the suggested or identified } \\
\text { interventions proposed by } \\
\text { the BEA were more } \\
\text { effective than the teacher } \\
\text { suggested interventions, due } \\
\text { to limited specificity and at } \\
\text { times misjudgments" (p. } \\
\text { 368). In this study, it was } \\
\text { noted that "none of the } \\
\text { teachers selected the same } \\
\text { intervention for their student }\end{array}$ \\
\hline
\end{tabular}




\begin{tabular}{|l|l|l|l|}
\hline & & $\begin{array}{l}\text { versus BEA } \\
\text { suggestion } \\
\text { intervention. }\end{array}$ & $\begin{array}{l}\text { that was identified most } \\
\text { promising in the BEA" (p. } \\
\text { 368). Having said that, it } \\
\text { can be noted that even the } \\
\text { most novice and } \\
\text { experienced teachers could } \\
\text { be further supported in } \\
\text { making the best decisions } \\
\text { about interventions for their } \\
\text { students. }\end{array}$ \\
\hline
\end{tabular}

To distinguish among the studies, a table has been included to identify the strengths, weaknesses, and gaps of each literature review article. This table can be viewed as the fine-tuning process of the readings, allowing the opportunity to "make subjective evaluations" (Galvan \& Galvan, 2017, p. 58). In formulating the table, the information gathered under each column may present such information that supports "research methods improving on the data-gathering techniques of earlier studies" (strength) or information depicting the methodologies to be "inappropriate" (weakness) (p. 58).

Table 4 is comprised of 3 columns. Column one lists the author and publication year. Column two lists the strengths, weaknesses, or gaps found in the article. The last column lists meaningful quotes from the article. Not all articles will have information under each area. Some articles had strengths and weaknesses, but no gap was identified.

Table 4. Strengths, Weaknesses, Gaps, and Direct Quotes in Literature

\begin{tabular}{|c|c|c|}
\hline $\begin{array}{c}\text { Authors and } \\
\text { Publication Year }\end{array}$ & Strengths, Weaknesses or Gaps & Meaningful Quotes \\
\hline $\begin{array}{l}\text { Coyne, Leonard } \\
\& \text { Burns (2016) }\end{array}$ & $\begin{array}{l}\text { Strengths: } \\
\text { - Literacy leadership such as school } \\
\text { literacy leadership teams, a dynamic } \\
\text { school literacy plan, and activity } \\
\text { timelines documenting progress (p. } \\
\text { 83). } \\
\text { - Consistent support from professional } \\
\text { staff, continuous modeling and } \\
\text { feedback opportunities (p. } 80) \text {. } \\
\text { Weakness: } \\
\text { - "Unaccountability of an experimental } \\
\text { study of the impact of the initiative } \\
\text { given that this was a pilot study" (p. } \\
\text { 83). }\end{array}$ & $\begin{array}{l}\text { "Many schools underestimate } \\
\text { the systems, structures, and } \\
\text { routines that are necessary to } \\
\text { ensure that MTSS reading } \\
\text { practices are implemented } \\
\text { with integrity, quality, and } \\
\text { consistency" (Coyne, } \\
\text { Leonard, \& Burns, 2016, p. } \\
\text { 83). }\end{array}$ \\
\hline
\end{tabular}




\begin{tabular}{|c|c|c|}
\hline Glover (2017) & $\begin{array}{l}\text { Strengths: } \\
\text { - Use of data-driven coaching model } \\
\text { - Practiced opportunities with feedback } \\
\quad \text { (p. 14). }\end{array}$ & $\begin{array}{l}\text { "Research on the data-driven } \\
\text { instructional coaching model, } \\
\text { which can be used to support } \\
\text { teachers in managing } \\
\text { behaviors and providing } \\
\text { instruction in multiple } \\
\text { content areas, has } \\
\text { documented its impact on } \\
\text { teachers' and } \\
\text { interventionists' knowledge, } \\
\text { self-efficacy, perceptions, } \\
\text { and practices pertaining to } \\
\text { data-based decision making } \\
\text { and the delivery of early } \\
\text { reading interventions" (p. } \\
\text { 19). }\end{array}$ \\
\hline Munro (2017) & $\begin{array}{l}\text { Strengths: } \\
\text { - } \quad \text { Total of } 902 \text { students } \\
\text { - } \quad \text { Divided into two cohorts, between } \\
\text { grades 1-4 (p. 136). } \\
\text { Weakness: } \\
\text { - Participating schools were Catholic } \\
\text { schools as opposed to public } \\
\text { education schools. } \\
\text { Gap: } \\
\text { - Gender and age were not recorded as } \\
\text { variables (p. 136). }\end{array}$ & $\begin{array}{l}\text { "The analysis of "what } \\
\text { works" in reading } \\
\text { intervention allows educators } \\
\text { to enhance the effectiveness } \\
\text { of their teaching and to } \\
\text { optimize student literacy } \\
\text { outcomes" } \\
\text { (p. 149). }\end{array}$ \\
\hline $\begin{array}{l}\text { Tyler, Hughes, } \\
\text { Beverley, \& } \\
\text { Hastings (2015) }\end{array}$ & $\begin{array}{l}\text { Strength: } \\
\text { - } 45 \text {-minute daily sessions during } 8 \\
\text { months, Eighty 20-minute lessons, } 80 \\
\text { stories, pre and post-reading } \\
\text { assessments (p. 284). } \\
\text { Weakness: } \\
\text { - Gender imbalance between both study } \\
\text { groups. "The HER group comprised } \\
\text { of } 6 \text { females and } 9 \text { males, while the } \\
\text { control group comprised } 3 \text { females } \\
\text { and } 13 \text { males" (p. 291). }\end{array}$ & $\begin{array}{l}\text { "It is a crucial aspect of the } \\
\text { implementation that the data } \\
\text { from benchmark assessments } \\
\text { are used in conjunction with } \\
\text { the episode data to make } \\
\text { instructional decisions" (p. } \\
\text { 291). }\end{array}$ \\
\hline
\end{tabular}




\begin{tabular}{|c|c|c|}
\hline $\begin{array}{l}\text { Wagner, } \\
\text { Coolong-Chaffin, } \\
\text { \& Deris (2017) }\end{array}$ & $\begin{array}{l}\text { Strength: } \\
\text { - Teacher interviews held prior and } \\
\text { post of study, brief experimental } \\
\text { analysis (BEA) was used in the study } \\
\text { (p. 351). } \\
\text { Weakness: } \\
\text { - A small pool of participants of only } 3 \\
\text { teachers and } 3 \text { students, suburban } \\
\text { areas (p. } 352) \text {. }\end{array}$ & $\begin{array}{l}\text { "Initial findings from the } \\
\text { teacher interviews revealed } \\
\text { that although teachers report } \\
\text { using data to make decisions, } \\
\text { they are unable to describe } \\
\text { specifically how they do so } \\
\text { and make decisions based on } \\
\text { other information" } \\
\text { (p. 368). }\end{array}$ \\
\hline
\end{tabular}

Figure 2 serves as a visual representation of the findings mentioned in text. The visual was created in a manner to assist the understanding of how each factor then branches out to mini factors. The mini factors each paid contribute in support of the overall goal of implementation.

\section{Discussion and Findings}

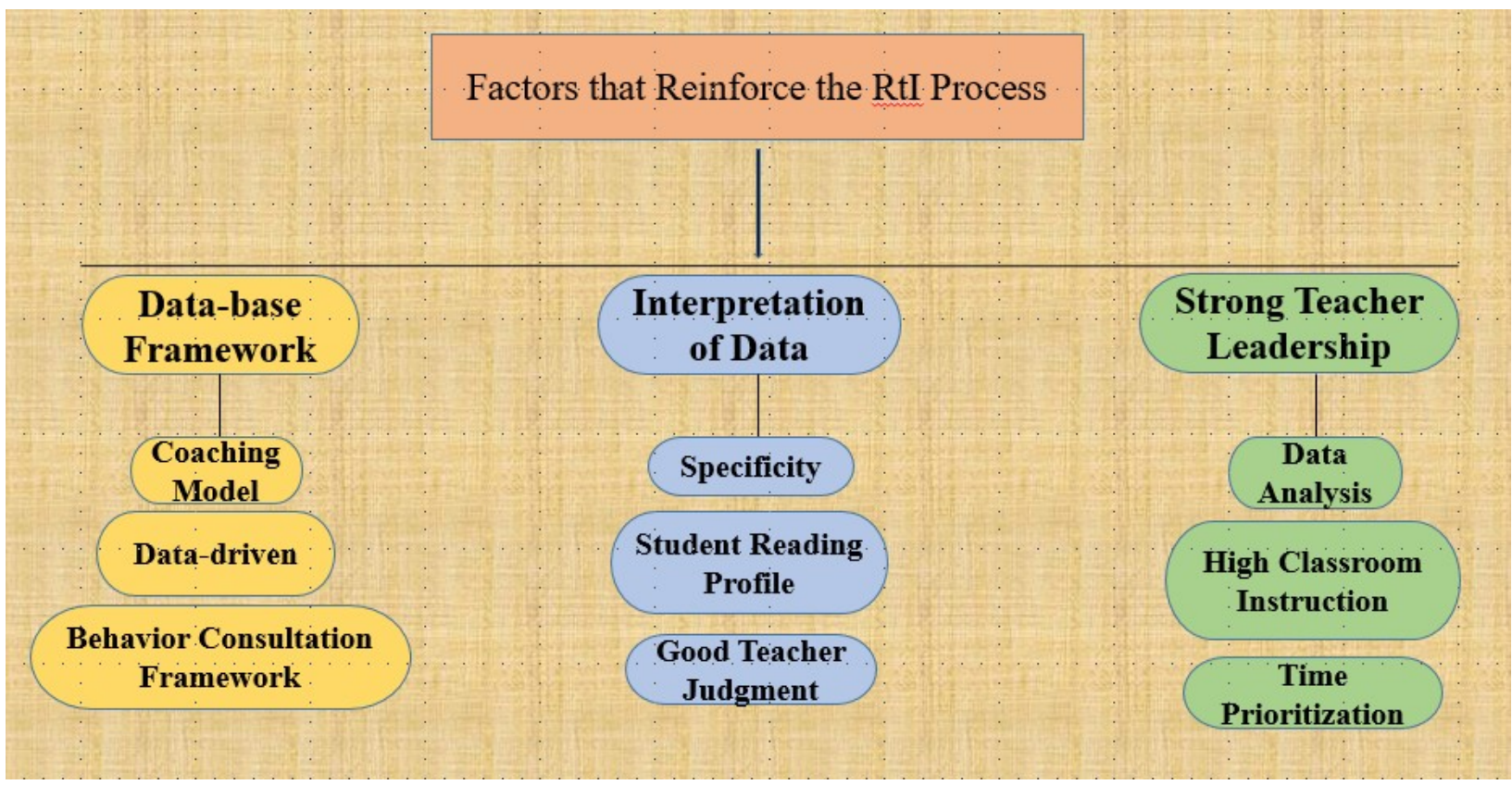

Figure 2. Factors that Reinforce the RtI Process

One factor that was crucial in reinforcing the RtI approach was the use of a data-driven coaching model (see Figure 2). In one case in the study, a Data-Driven Coaching Model was used as the implementation process for RtI. The coaching model was comprised of 3 main components: emphasis on the learning environment, enrollment of teachers via modeling, designated opportunities for feedback, and the use of a formalized data-driven implementation framework. The focus in this approach was to fully provide the teacher with all of the necessary tools and preparation needed for RtI implementation. Participating teachers were individually teamed with an experienced intervention coach that would serve as a facilitator for the teacher throughout the entire RtI process. Throughout, the teacher was 
provided with ample opportunities for modeling and feedback. The teacher was guided during the intervention process as well as with the prior collection and interpretation of data analysis. The intervention coach assisted the teacher in deciphering individual student reading profiles and in making a judgment as to what intervention activity to propose for the student and their individual needs. With this approach, which is guided by a behavior consultation framework, "change is presumed to occur as a result of the influence of coaching actions and teachers' perceptions and self-efficacy" (Glover, 2017, p. 19).

In this case in study, the findings explain how a data-driven coaching model helps zoom in on the behavior and environment of the teacher rather than that of the student, and how to build on the teacher's abilities to perform. After having reviewed this particular case, I found myself relating to it in more ways than one. As educators, do we not deliver instruction to our own students in this similar approach? We provide ample opportunities for modeling and provide feedback to our students during the learning process. We guide our students throughout the instruction and gradually release as we observe student growth and confidence, just as the coaches provided to the participating teachers and interventionists in the study. As teachers, we fill our students' buckets with positive praise and reinforcement so that they will gain confidence and success; just as the teachers, in this case, walked away after the study with a gaining of self-efficacy and self-confidence. "The data-driven instructional coaching model extends the focus beyond behavioral change to incorporate changes in instructional practices and skills" (Glover, 2017, p. 14). The foundation of the model of coaching support serves as a catalyst that drives positive outcomes for both the teacher as well as the student.

Another factor noted to be a crucial part in reinforcing intervention was data analysis and the teacher's interpretation of data. In the second case in the study, participating teachers were interviewed as to how they analyzed and interpreted student data in respect to RtI. In the pre- and post-interviews, the use of a brief experimental analysis (BEA) was used as a means of obtaining a variety of reading interventions appropriate for early readers. "Initial findings from the teacher interviews revealed that although teachers report using data to make decisions, they are unable to describe specifically how they do so and make decisions based on other information" (Wagner, Coolong-Chaffin, \& Deris, 2017, p. 368). In other words, the participating teachers were exemplifying great knowledge in gathering data but were not making good teacher judgment as to how to use the data. As educators, we do administer an overflow of assessments. They can vary between a phonics pre-assessment at the beginning of the year, a fluency running record throughout, or perhaps a reading benchmark at a midway point in the year. The wealth of data gathered is surreal. Though what then? As educators, do we fully understand how to implement the data into instruction or means of intervention? Or are we simply going through the motion of assessment and data gathering in hopes that we make a solid judgment in respect to intervention? "The findings in this study presented that the suggested or identified interventions proposed by the BEA were more effective than the teacher-suggested interventions, due to limited specificity and at times misjudgments" (p. 368). In this study, it was noted that "none of the teachers selected the same intervention for their student that was identified most promising in the BEA" ( $p$. 
368). Having said that, it can be noted that even the most novice and experienced teachers could be further supported in making best decisions about interventions for their students and their individual needs.

A final factor and one in which I feel is the most impactful, is the factor of strong teacher leadership in connection to administrative support. In a final case in study, participating schools implemented a K-3 Reading Initiative, in which goals were to "implement and evaluate a fully specified school-wide multi-tiered K-3 reading school improvement model" (Coyne, Leonard, \& Burns, 2016, p. 69). This improvement model was considered to be a complex model all around. The model consisted of various steps and stages of "developing systems, organizational structures, and routines that are aligned, coordinated, and implemented consistently" (p. 70). This particular model required full support from administration and stake holders as foundation for success. If a school does not take the time nor make priority in delving into the details when implementing an MTSS model, it is then that their efforts can be impeded by barriers. Barriers can be factors such as lack of support, lack of resources, or even an overwhelming population of students in need of intervention within a high-priority school. The MTSS reading school improvement model consisted of components that were crucial to the overall implementation. Such components were literacy leadership, high-quality classroom reading instruction, data use to inform instruction and intervention, and small group instruction for all students (p. 83).

As teachers, we know that in the world of education we do not have the luxury of time. Sadly that is the raw truth. From the beginning of an academic year to the end, the year is compacted with time-consuming motivational events, fundraisers, field trips, staff meetings, state testing dates, and numerous other events. The list is never-ending. Though a sad reality is that schools tend to not make time to insert a time frame for thorough planning of intervention. Just as there are timeslots embedded into a campus academic schedule for other areas of topic and concern, there should also be a designated time for RtI planning and implementation. The school as a whole must prioritize the time to reflect on a current campus or district RtI plan and delve into the details on how to appropriately and consistently implement, and with fidelity. We feel it is important to keep in mind exactly what it is that the findings in this study imply. Not only was the multi-tiered system of support implemented and deemed effective, but more so, it was the administrative support and diligent work ethic of the staff and that made the obvious impact. "The supports that schools need to build systems and infrastructure to implement and sustain such practices are often overseen" (Coyne, Leonard, \& Burns, 2016, p. 68). "Many schools underestimate the systems, structures, and routines that are necessary to ensure that MTSS reading practices are implemented with integrity, quality, and consistency" (p. 83).

\section{Implications}

Response to Intervention is a process that is connected to underlying factors that serve as a strong foundation for the implementation. Having said that, an interest that was the drive throughout the literature review was that of determining what those specific factors were. Some areas of interest where factors were thought to be discovered were in areas such as best 
practices or highly recommended RtI programs within districts. Though, at completion it was clear that the factors did not reside within those boundaries at all. Throughout the literature review it was understood that the patterned factor that brought RtI implementation to such success was that of administrative support. Administrative support provided to the RtI process can literally be viewed as the backbone to RtI success, or any implementation at that. Support can be described through a variety of scenarios. One for instance is that it is key for administration to embrace RtI and its importance and relevance to the student body at need. In addition to, it is important for stake holders such as administration, key teachers, and RtI coordinators to honor support and belief of the process itself. Believing that the process is being implemented for the best interest of the students who will be participating in the intervention.

Another scenario that mirrors a support system can be the example of a campus master schedule already embedded with a specific RtI block designating time and focus for this process. Providing a set time in the master schedule can deter from future road blocks such as scheduling of groups. Support can also consist of providing on-going staff development for faculty and RtI staff as they can acquire new data and current legalities that relate to RtI. While the RtI process is being implemented and administered, staff can then utilize that knowledge of information in terms of making any adjustments as needed along the way. As noted the factor all along was not at all in the making of any new discoveries in the world of education. Rather, it was a tool that many districts already do have right at arms-length. Administrative support can absolutely be viewed as the driving force behind any learning process that is set in place for children. This works. "The analysis of what works in reading intervention allows educators to enhance the effectiveness of their teaching and to optimize student literacy outcomes" (Munro, 2017, p. 149). Through this support, not only will staff fulfill their duties, but furthermore they will fulfill them with the appropriate knowledge, confidence, and self-efficacy.

\section{References}

Coyne, M., Oldham, A., Leonard, K., Burns, D., \& Gage, N. (2016). Delving into the details: Implementing multitiered K-3 reading supports in high-priority schools. New Directions for Child and Adolescent Development, (154), 67-85. https://doi.org/10.1002/cad.20175

Galvan, J. L., \& Galvan, M. C. (2017). Writing literature reviews: A guide for students of the social and behavior sciences ( $7^{\text {th }}$ ed.). New York, NY: Routledge.

Glover, T. (2017). A data-driven coaching model used to promote students' response to early reading intervention. Theory into Practice, 56(1), 13-20. Accessed from https://tamiu.on.worldcat.org/oclc/7132247379

Munro, J. (2017). Who benefits from which reading intervention in the primary years? Match the intervention with the reading profile. Australian Journal of Learning Difficulties, 22(2), 133-151. Accessed from https://tamiu.on.worldcat.org/oclc/7585347557

Tyler, E., Hughes, J., Beverley, M., \& Hastings, R. (2015). Improving early reading skills for beginning readers using an online programme as supplementary instruction. European 


\section{Macrothink}

Journal of Studies in Education ISSN 2162-6952 2019, Vol. 9, No. 4

Journal of Psychology of Education: A Journal of Education and Development, 30(3), 281-294. https://doi.org/10.1007/s10212-014-0240-7

Wagner, D., Coolong-Chaffin, M., \& Deris, A. (2017). Comparing brief experimental analysis and teacher judgment for selecting early reading interventions. Journal of Behavioral Education, 26(4), 348-370. https://doi.org/10.1007/s10864-017-9281-8 